\title{
Araştırmal Research
}

\section{TÜRKIYYE'DEKİ ÇEVRE LABORATUVARLARININ ÇEVRESEL SÜRDÜRÜLEBİLIRLİĞININ YEŞİL LABORATUVAR SERTIFİKASI ILE DEĞERLENDİRILMESI}

\author{
Gülnihal KARA ${ }^{1}$ (ORCID: 0000-0002-1955-1596) ${ }^{*}$ \\ ${ }^{1}$ Konya Teknik Üniversitesi, Çevre Mühendisliği Bölümü, 42075 Kampus, Konya, Türkiye
}

Gelis / Received: 28.08 .2018 Kabul / Accepted: 15.01.2019

\begin{abstract}
ÖZ
Çevre laboratuvarları rutin kullanımlarında basit solvent, su veya özel bertaraf gerektiren biyolojik veya kimyasal tehlikeli atıklar gibi çok çeşitli ve çok miktarlarda atık üretmektedir. Yeşil Laboratuvar sertifikası, laboratuvarın sürdürülebilirliğini arttırmak için ilkeler belirleyen bir sertifikasyon yöntemidir. Yeşil laboratuvar sertifikasının sadece kuruluş veya firmalar değil, ülke ve bölgeler içinde önemli risk yöntemi ve rekabet avantajları sağladığı bilinmektedir. $\mathrm{Bu}$ çalışma da Türkiye'deki çevre laboratuvarlarının çevresel sürdürülebilirliği 31 yeşil laboratuvar ilkesine göre anket tekniği kullanılarak değerlendirilmiştir.
\end{abstract}

Anahtar Kelimeler: Türkiye'de Çevre laboratuvarları, çevresel sürdürülebilirlik, yeşil laboratuvar sertifikası

\section{ASSESSMENT WITH GREEN LABORATORY CERTIFICATION OF THE ENVIRONMENTAL SUSTAINABILITY OF THE ENVIRONMENTAL LABORATORIES IN TURKEY}

\begin{abstract}
Environmental laboratories create a lot amount of waste in the routine use; waste products range from simple solvents, such as water, to biologically or chemically hazardous wastes that require special disposal. The Green Laboratory certificate is a certification method that determines principles to increase the sustainability of the laboratory. It is known that green laboratory certification provide significant risk methods and competitive advantages within countries and regions, not just individual organizations or companies. In this study, the environmental sustainability of environmental laboratories in Turkey was evaluated according to the 31 principles of green laboratory using survey techniques.
\end{abstract}

Keywords: Environmental laboratories, environmental sustainability, green laboratory certification, Turkey

\section{GíRiș}

Çevre kirliliği ile ilgili farkındalık Türkiye'de her yıl daha da artmaktadır. Ülkeler, sürdürülebilir çevre politikalarına daha çok önem vermekte ve tüketiciler ürünlerin çevresel etkileri konusunda daha da bilinçlenerek daha çevre dostu ürünleri tüketmeye eğilim göstermektedir. Türkiye'nin Avrupa ve diğer ülkeler için büyük bir

*Corresponding author / Sorumlu yazar. Tel.: 03322238818 ; e-mail / e-posta: gkara@ selcuk.edu.tr 
üretim merkezi olması ve beraberinde ürünlerini daha kolay pazarlayabilmesi için daha çevre dostu ve sürdürülebilir bir gelişmeye sahip olması gerekir.

Çevresel etiketler veya belgeleme/sertifika sistemleri, üçüncü taraflarca belirlenen ölçütlere uygunluğu açısından çevresel etkileri değerlendirilen ürünlere/hizmetlere, bu değerlendirme sonucunda verilen ve alınması gönüllülüğe dayanan etiketler veya belgeler/sertifikalardır. Her ne kadar çevre ile ilgili bütün etiketler "yeşiletiket" olarak anılsa da, çevresel performansa ilişkin çok sayıda etiket ve belgeleme sistemi bulunmaktadır [1]. Yeşil etiket, tüm faaliyetlerde uygulanmak istenen ve temelinde faaliyetlerin sürdürülebilirliğinin öz kaynaklarla sağlanması ve çevreye etkinin ortadan kaldırılması veya en aza indirilmesinin, faaliyetler tarafından sağlandığının göstergesi olarak bazı kuruluş veya üniversiteler tarafından uygulamaya geçirilen sertifikasyon çalışmasıdır. ISO (Uluslararası Standardizasyon Örgütü), ISO/COPOLCO (ISO - Tüketici Politikaları Komitesi) adı altında 1989 yılında, çeşitli çevresel etiketleme/belgeleme/sertifika programları arasında üst ilkeler doğrultusunda bir uyumluluk sağlanması amacı ile SAGE (Çevresel Stratejik Danışma Grubu)'nu kurmuştur. Bu doğrultuda 1993 yılında çevresel etiketleme/belgeleme/sertifikaprogramlarının TİP 1, TİP 2 ve TİP 3 olmak üzere 3 grupta değerlendirilmesine karar verilmiştir [2, 3, 4]. Ülkemizde 2010 yılında yürürlüğe giren“'İyi Laboratuvar Uygulamaları Prensipleri, Test Birimlerinin Uyumlaştırılması, İyi Laboratuvar Uygulamalarının ve Çalışmaların Denetlenmesi Hakkında Yönetmelik" ile insan sağlı̆̆ı ve çevre korunarak zaman, maliyet, kaynak tasarrufu gözetilerek test verilerinin kalitesinin ve güvenilirliğinin güvence altına alınması amaçlanmıştır [5]. Yeşil Laboratuar (GreenLab) sertifikası ile çevresel sürdürülebilirlik temelinde karşılaştırıldığında atık bertarafı ve kısmen diğer konuların benzerlik gösterdiği söylenebilir. Ancak yönetmelikte laboratuvar işleyişi, çalışanların sorumlulukları ve denetim ile ilgili konular daha ön plandadır.

Yeşil Laboratuvar (GreenLab) sertifikası ise çevreye etkisi azaltılmış, yapımından işletmesine ve sonrasındaki süreçlerine kadar doğa dostu, yenilenebilir, geri dönüştürülebilir veya yeniden kullanılabilir malzeme ve kaynakları kullanan laboratuvarlara verilen sertifikadır [6]. USA, Almanya, Fransa gibi gelişmiş ülkelerde laboratuvarların çevresel sürdürülebilirliği Yeşil Laboratuar Sertifikası ile değerlendirilmektedir. Yeni kurulacak olan laboratuarlar, gerekli teşvikler sağlanarak ise mevcut laboratuvarların tamamının yeşil laboratuar (GreenLab) sertifikasına sahip olması konusunda çalışmalar devam etmektedir [7]. Yeşil Laboratuar Sertifikası ile değerlendirme, laboratuvarların mevcut güvenlik ve sürdürülebilir uygulamalarının onaylanmasına izin verir ve laboratuvarların çevresel etkilerini azaltmalarına yönelik öneriler sunar. Değerlendirmede ele alınan temel konular; enerji verimliliği, su tasarrufu, tehlikeli kimyasalların kullanımı ve uzaklaştırılması, eğitim, geri dönüşüm-yeniden kullanım dır [8]. Yeşil Laboratuar Sertifikalı laboratuvarlar, mümkün olduğunca yeşil kimya ilkelerine göre deney tasarlamalıdır. Yeşil kimya; çevre kirliliğinin önlenmesi için oldukça etkili bir yaklaşımdır. US EPA'ya göre yeşil kimya; kimyasalların veya kimyasal analizlerin çevreye olumsuz etkilerini azaltma veya ortadan kaldırma faaliyetleridir. Yeşil kimya; kimyasalların tasarlanması, üretimi, kullanımı ve kullanım sonrası ortaya çıkabilecek olumsuzlukları bertaraf eden veya azaltan yeni teknolojilerin geliştirilmesini teşvik etmektedir. Bu yaklaşım, alternatiflerinden daha fazla kaynakların korunmasını sağlar. Yeşil kimya ilkelerinde deneylerde mümkün olduğunca tehlikeli olmayan güvenli kimyasal kullanımı vurgulanmaktadır. Yeşil kimyanın "12 ilkesi” yeşil kimyayı uygulamak için bir yol haritası sunmaktadır. Bu 12 ilke; atıkların önlenmesi, atom ekonomisi yani deneylerin verimi yüksek, maksimum ürün ve minimum atık üretimine göre tasarlanması, çevre ve insan sağlığı açısından zararlı bir sentez tekniği yerine daha az zararlı başka bir alternatifin tercih edilmesi, daha güvenli kimyasallarla deney tasarlama, aşırı ve gereksiz çözücü veya kimyasalların kullanımından kaçınılması ve çevre ve insan sağlığı açısından daha az zararsız olanların tercih edilmesi, deneylerde enerjinin verimli kullanımı, yenilenebilir hammadde kullanımı, ilave reaktif gerektiren uygulamaları azaltma- kaçınma, katalitik reaktiflerin kullanılması, deneylerin kimyasal ürünlerin kısa sürede zararsız bir şekilde bozunacak şekilde tasarlanması, kirliliğin önlenmesi için gerçek zamanlı analitik metotlar kullanabilen izleme ve kontrol sistemlerinin kurulması ve oluşabilecek kirlenmenin anında tespit edilerek önlemlerin geliştirilmesi, kimyasal proseslerin patlama, yangın gibi kazaları en aza indirilecek şekilde planlanması dır [9].

\section{MATERYAL VE METOT}

Bu çalışmada, Türkiye'de ki Çevre ve Şehircilik Bakanlığı tarafından Çevre Ölçüm ve Analiz Laboratuvarları Yeterlilik Yönetmeliği kapsamında farklı sayıda ve türde su ve atık su parametreleri için Akreditasyon Kurumu (TURKAK) tarafından onaylanmış akreditasyon belgesine sahip Çevre Ölçüm ve Analizleri Yeterlilik Belgesi almış kamu/özel sektör Çevre Laboratuvarlarının Yeşil Laboratuar Sertifika ilkelerine uygunluğu anket yöntemi ile değerlendirilmiştir. Toplamda 81 ilde bulunan 197 Çevre Laboratuvarına çoğunluğuna e-mail ve bazılarına facebook üzerinden, geri dönüş alınamayan bazı laboratuvarlara telefon ile 
ulaşılmış, 170 Çevre laboratuvarından yanıtlar gelmiş ve değerlendirmeler buna göre gerçekleştirilmiştir. Anket soruları Washington Üniversitesi Yeşil Laboratuvar sertifikası aplikasyonundan uyarlanarak oluşturulmuştur. Toplam 32 sorudan 2 tanesi laboratuvarın genel özelliklerini,1 tanesi eğitim faaliyetlerini belirlemek, 10 tanesi enerji verimliliğini, 3 tanesi su tüketimi ve verimliliğini ölçmek, 5 tanesi laboratuvarlarda kullanılan tehlikeli kimyasallar ve bunların nasıl uzaklaştıııldığını, 5 tanesi atık minimizasyonu faaliyetlerini, 6 tanesi laboratuvarda geri dönüşüm-yeniden kullanım ile ilgili yapılan çalışma ve alınan önlemleri anlamak amacıyla oluşturulmuştur. Çalışma da geliş̧irilen soru kategorileri, sorular, sayıları ve yanıt türleri tablo 1'de özetlenmiştir.

Puan hesaplamasına laboratuvarın genel özelliklerini belirlemek amacıyla (ekipman sayısı, çalışma alanı vb.) sorulan sorular dahil edilmemiştir. Toplam 32 sorudan 29 tanesi 100 puan üzerinden değerlendirilmiş ve yeşil laboratuar sertifika ilkelerine uygun verilen her yanıt 3.445 puan olarak kabul edilmiş ve puan skalasına göre [6] (Tablo 2) laboratuvarların puanları değerlendirilmiştir. Bu çalışma Türkiye'de faaliyet gösteren Çevre Laboratuvarlarının yeşil laboratuarilkelerine göre çevresel sürdürülebilirlikleri hakkında fikir edinmeyi amaçlamıştır.

Tablo 2.Yeşil Laboratuvar sertifikası puan skalası(GreenLaboratorycertificatescorescale)

\begin{tabular}{ccccc}
\hline Yeşil Lab.Sertifikası & Bronz & Gümüş & Altın & Platin \\
\hline $40-49$ & $50-59$ & $60-69$ & $70-79$ & $>80$ \\
\hline
\end{tabular}

\section{BULGULAR VE TARTIŞMALAR}

Bir laboratuvar birim yüzey alanına göre genel bir ofis binasından 3-6 kat veya daha fazla enerji kullanmaktadır [10]. Laboratuvarlarda enerji tüketimi; laboratuvar ekipmanlarının sayısı ve çalışma süresi, ventilasyon sistemleri ile ilişkilidir. Çeker ocaklar, davlumbazlar, derin dondurucu ve buzdolapları en fazla enerji tüketen cihazlardır. Günümüzde laboratuvarlarda buzdolabının yanı sıra derin dondurucularda kullanılmaktadır. Çevre Laboratuvarlarının verilen yanıtlara göre tamamında derindondurucu bulunduğu, ancak derindondurucuların 99 laboratuvarda 7 yıl veya daha uzun zaman önce alındığı tespit edilmiştir (Şekil 1). Eski cihaz ve ekipmanların tıpki araçlarda olduğu gibi daha fazla enerji tükettiği aşikârdır. Enerji verimlililiğini ölçen "Buzdolapları ve derin dondurucuların buz hazneleri düzenli olarak çözülüp ve temizleniyor mu?"sorusuna 87 laboratuvar "hayır" yanıtı vermiştir. Bu durum laboratuarların enerji verimliliği ile ilgili farkındalıklarının düşük olduğunu göstermiştir. Laboratuvarlarda enerji tüketiminin yaklaşık \%50-80'i nem ve sıcaklık kontrolü sağlayan ventilasyon sistemleri yüzündendir. Edinburg Üniversitesi-kanser araştırma merkezinde toplam $1243596 \mathrm{kwh} / \mathrm{y} 1 \mathrm{l}$ elektrik tüketiminin \%37'si ventilasyon sistemlerinden kaynaklanmaktadır [11]. Kaliforniya üniversitesindeki laboratuvarların alanı ofis binalarının onda biri olmasına rağmen toplam enerji tüketiminin \%60'ndan fazlasını tüketmektedirler [12]. Çeker ocaklar laboratuvarlarda en fazla gerekinim duyulan ekipmanlardır. Çeker ocak olan binaların enerji tüketimi tipik ticari binalara göre 4-5 kat daha fazladır [13]. Farklı hava hacimlerine ve farklı pozisyonlara ayarlanabilir Çeker ocak veya davlumbazlar enerji maliyetini düşürecektir [14]. Berkeley tipi davlumbazlarda kullanılan özel bir başlık ile kullanıcının ön tarafı temiz hava beslenir, bu başlık ile kimyasal buhar ve kirletici gazlar yalnızca\% 20-40 oranında çekilerek hem enerji maliyetleri azaltılır hem de kullanıcının önünde kirletici olmayan ortam sağlar [13].Davlumbazlar, güvenlik endişeleri nedeniyle kullanımları arasında kapatılmadığında enerji tasarruf modunda çalışması sağlanmalıdır. Ancak yeni üretilen davlumbazlarda metaloksitdedektörleri, gaz doygunluk ve asit uyarı göstergeleri ile güvenlik endişeleri azaltılmıştır [15]. Verilen yanıtlara göre anket çalışmasına katılan çevre laboratuvarlarının 117 sinde davlumbaz ve çeker ocak bulunmakta ve neredeyse tamamında 109 laboratuvarda davlumbazlar kullanılmadıkları dönemde kapatılmaktadır. 
G. KARA

Tablo 1. Yeşil Laboratuar Sertifika ilkelerine uygunluğu ölçmek amaciyla geliştirilmiş anket soru kategorileri ve sayıları

\begin{tabular}{|c|c|c|c|}
\hline Kategori & \begin{tabular}{|c|} 
Soru \\
Say1s1 \\
\end{tabular} & Araştırma Soruları & Yanitlar \\
\hline $\begin{array}{|lr|}\text { Laboratuarın } & \text { genel } \\
\text { özelliklerini } & \\
\text { betimlemeye } & \text { yönelik } \\
\text { olgusal soru } & \\
\end{array}$ & 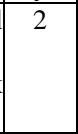 & $\begin{array}{l}\text { Laboratuarın çalışma alanı-akredite parametreleri/sayısı ve laboratuarda } \\
\text { çevre ile ilgili çalışmalar yürüten birimin var olup olmadığı, Belediyeler } \\
\text { veya kurumlarla yürütülen ortak çalışmalar, yapılan veya yapilması } \\
\text { planlanan düzenleme ve yeniliklerin varlığı }\end{array}$ & \\
\hline \begin{tabular}{|l} 
Laboratuarın \\
faaliyetlerini \\
belirlemeye \\
bilgi soritim
\end{tabular} & 1 & $\begin{array}{l}\text { Laboratuar da panolara sürdürülebilir çalışmalarla ilgili bilgilendirmelerin } \\
\text { yapılıp yapılmadığı, çevresel etkilerini azaltmak amacıyla yapmayı } \\
\text { planladıkları faaliyetleri }\end{array}$ & $\begin{array}{l}\text { Evet/Hayır ve } \\
1 \text { Açık uçlu soru }\end{array}$ \\
\hline $\begin{array}{lr}\text { Laboratuarın } & \text { enerji } \\
\text { verimliliğini } & \\
\text { belirlemeye } & \text { yönelik } \\
\text { bilgi soruları } & \end{array}$ & 10 & $\begin{array}{l}\text { Son iki yıl içinde alınan ekipman sayısı ve ekipmanların, buzdolabı ve } \\
\text { dondurucuların alımında enerji yıldızının göz önüne alınıp alınmadığı, } \\
\text { buzdolapları ve derin dondurucuların buz haznelerinin düzenli olarak } \\
\text { temizlenip temizlenmediği, çok fazla elektrik tüketen dondurucu, } \\
\text { biyogüvenlik kabini, davlumbazların varlığı, bu ekipmanların kullanılırken } \\
\text { düşük pozisyonda kullanılıp kullanılmadığı, kullanılmadıklarında kapatılıp } \\
\text { kapatılmadığı, sürekli kullanılan ekipmanların (kişisel bilgisayarlar, fanlar, } \\
\text { fırınlar ve gaz kromatograf vb.) kullanılmaklarında kapatılıp kapatılmadığı, } \\
\text { laboratuar kullanımda değilken 1şıkların kapalı olup olmadığı, 1şık } \\
\text { anahtarları/ekipmanların üzerinde hatırlatma çıkartmalarının var olup } \\
\text { olmadığı, satın alımlarda elektronik ve online alışverişin tercih edilip } \\
\text { edilmediği }\end{array}$ & \\
\hline $\begin{array}{|lr|}\text { Laboratuarın } & \mathrm{su} \\
\text { tüketimi } & \mathrm{ve} \\
\text { verimliliğini } & \\
\text { belirlemeye } & \text { yönelik } \\
\text { bilgi soruları } & \\
\end{array}$ & 3 & $\begin{array}{l}\text { Bina yöneticilerine lavabo veya herhangi bir boru/borulardaki su sızıntısının } \\
\text { rapor edilip edilmediği, su tasarrufu ile ilgili eğitimlerin verilip verilmediği, } \\
\text { standartlaşmış uygun yıkama tekniklerinin oluşturulup oluşturulmadığı, cam } \\
\text { malzemelerin temizliğinde standartlaşmış hacimlerde çözücü kullanılıp } \\
\text { kullanılmadığı }\end{array}$ & \\
\hline $\begin{array}{l}\text { Laboratuarın geri } \\
\text { dönüşüm-yeniden } \\
\text { kullanım faaliyetlerini } \\
\text { belirlemeye yönelik } \\
\text { bilgi soruları }\end{array}$ & 6 & $\begin{array}{l}\text { Laboratuvarda geri dönüştürülebilecek veya yeniden kullanılabilecek } \\
\text { materyal ve malzemelerin, değerlendirilip değerlendirilmediği, satın almada } \\
\text { geri dönüştürülebilen ambalajlı ürünlerin tercih edilip edilmediği, yeniden } \\
\text { kullanılabilir malzeme ve geri dönüştürülebilir kimyasalların kullanılıp } \\
\text { kullanılmadığı, rapor vb. kullanımlar için geri dönüşümlü kâğıt kullanılıp } \\
\text { kullanılmadığı, şarj edilebilen pillerin kullanılıp kullanılmadığı, pillerin geri } \\
\text { dönüştürülüp dönüştürülmediği, }\end{array}$ & \\
\hline $\begin{array}{l}\text { Laboratuarın atık } \\
\text { minimizasyonu ile ilgili } \\
\text { faaliyetlerini } \quad \text { yönelik } \\
\text { bilgi soruları }\end{array}$ & 5 & $\begin{array}{l}\text { Laboratuarda kullanılan, depolanan ve üretilen kimyasalların rutin olarak } \\
\text { sayımının yapılıp yapılmadığı, kimyasal madde alımlarının ihtiyaca göre } \\
\text { veya gereğinden fazla alınıp alınmadığı, kimyasallardan ve depolamadan } \\
\text { sorumlu kişi/kişilerin varlığı, satın almada gereksiz malzeme satın alımını } \\
\text { önlemek için danışma biriminin varlığı, fazla miktarda satın alınmış } \\
\text { kimyasal/malzemelerin fazlasını korumak için herhangi önlem alınıp } \\
\text { alınmadığı }\end{array}$ & Evet/Hayır \\
\hline $\begin{array}{l}\text { Laboratuarın } \text { tehlikeli } \\
\text { kimyasal kullanımını } \\
\text { ve bu kimyasalların } \\
\text { nasıl uzaklaştırıldığını } \\
\text { belirlemeye rönelik } \\
\text { bilgi soruları }\end{array}$ & 5 & $\begin{array}{l}\text { Laboratuarda yeşil sertifikalı temizlik ürünlerinin kullanılıp, kullanılmadığı, } \\
\text { bitkisel içerikli laboratuar materyallerinin tercih edilip, edilmediği, } \\
\text { kullanılan kimyasalların güvenli bir şekilde depolanıp depolanmadığı, } \\
\text { tehlikeli kimyasalların tanımlanıp daha az tehlikeli alternatiflerinin tercih } \\
\text { edilip edilmediği, halojenli reaktiflerin tercih edilip edilmediği }\end{array}$ & Hayır \\
\hline
\end{tabular}




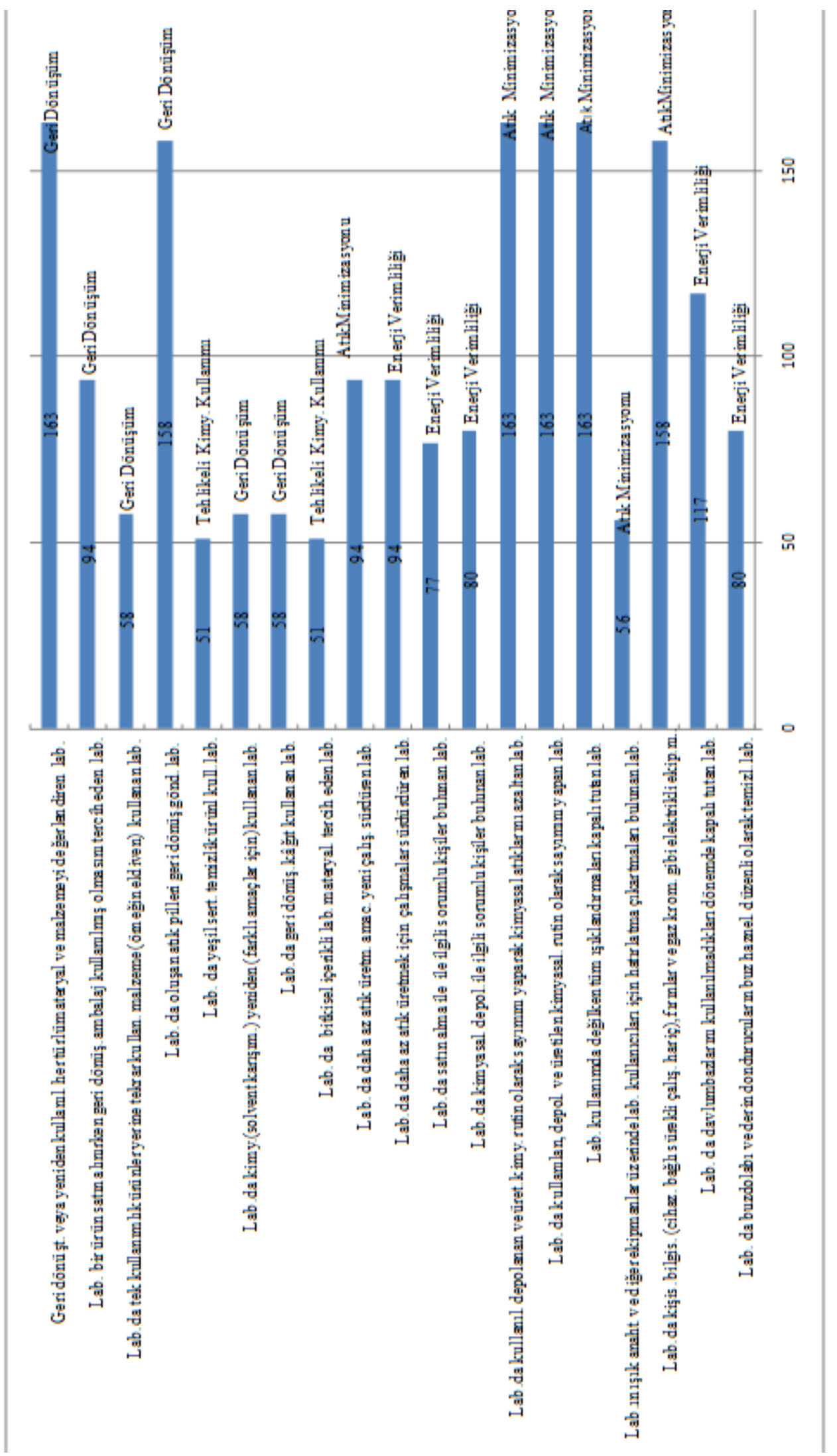

Şekil 1. Çevresel sürdürülebilirlik değerlendirme anket sonuçları 
Diğer fark edilebilir enerji tüketen kaynak ise uzun süre açık bırakılan bilgisayarlar ve onlarla ilişkili ekipmanlardır. Genel olarak bilgisayarlar LCD ekranlı tercih edilerek, enerji tasarruf modunda çalıştırılarak ve ekran koruyucu kullanmayarakelektrik tüketimi azaltılabilir. Laboratuvarda çalışan gruplar laboratuarı terk edip, tekrar laboratuara geldiklerinde hızlıca bigisayarları açabilmesi için bilgisayarlar daha az enerji tüketen uyku moduna ayarlanabilir veya ayarlandığı zamanlarda otomatik olarak kapanıp ekipmanı çalıştırabilen ve gerekmediğinde ekipmanı elektrikten kesebilen Outlettimers kullanılabilir. Sadece bilgisayarlarda değil tüm laboratuar ekipmanlarında outlettimers kullanıldığında enerji tüketimi \%50 azalmaktadır. Bu çalışma da bu konu ile ilgili laboratuvarların farkındalığı "Kişisel bilgisayarlar (cihazlara bağlı sürekli çalışanlar hariç), 1sı plakaları, fanlar, santrifüjler, firınlar ve gaz kromatograf gibi elektrikli ekipmanlar kullanılmadığı zaman kapalı durumda mıdır?"sorusu ile ölçülmüş ve bu soruya laboratuvarların büyük çoğunluğu 158 laboratuvar "evet" yanıtı vermiştir. Laboratuardaki sık kullanılmayan enstrümanların güç kablolarının çıkarılması enerji tasarrufu sağlayacaktır. [16]. Bazı laboratuvar odaları sadece ilkbahar veya kış dönemi kullanılır, böyle laboratuvar odalarının iklimlendirme cihazları dış ortam sıcaklığına ayarlanabilir. Bu tür küçük önlemlerle Washington üniveristesinde 16 laboratuvarda yıllık 80000 pound $\mathrm{CO}_{2}$ emisyonunda azalma 2,000 \$ kazanç sağlanmıştır [17]. Laboratuvarlarda bir diğer enerji tüketen kaynak ise aydınlatma sistemleridir. Alan aydınlatması yerine kullanılan çalışma alanlarını aydınlatan sistemler enerji tasarrufu sağlayacaktır [12]. Bu konu ile ilgili "Laboratuvar kullanımda değilken 1şıkları kapalı mıdır?" sorusuna laboratuvarların büyük çoğunluğu 163 laboratuvar "evet" yanıtı vermiştir. Enerji tasarrufunu arttırma amacıyla alınacak önlemlerden biri de hatırlatma çıkartmalarıdır. "Laboratuvarın 1şık anahtarları üzerine laboratuvar boş olduğunda 1şıkları kapatmak için laboratuvar kullanıcılarına hatırlatma çıkartmaları var mı? Sorusuna maalesef 114 laboratuvar "hayır"yanıtını vermiştir.

Laboratuvarlarda atık minimizasyonu ancak kullanılan kimyasalları minimize ederek gerçekleşebilir [7]. Labaratuvarların tamamındaki stoklar birleştirilerek gereksiz kimyasal satın alımı azaltılarak hem para tasarrufu hem de kullanılmamış ancak son kullanma tarihi geçmiş kimyasalların oluşturduğu atık miktarı da azalmış olacaktır. Bazı bilgisayar yazılımları ile hem kimyasalın konumu hem de kullanımı kimyasal konteynırın üzerine yapıştırılan barkodlarla izlenebilir [18]. Ayrıca laboratuvarlarda kimyasalların satın alınması, depolanması ile ilgili sorumlu kişilerin bulunması gereksiz kimyasal alımını ve atık oluşumunu azaltacaktır. Bu çalışma da Türkiye'deki çevre laboratuarlarının büyük çoğunluğu (163 laboratuvar) laboratuvarında kullanılan, depolanan ve üretilen kimyasalların rutin olarak sayımının yapılarak kimyasal atıkların en aza indirildiğini belirtmişlerdir. Ancak bu çalışma da anketlere verilen yanıtlara göre sadece 80 laboratuvarda kimyasalların depolanması,77 laboratuvarda da satın alma ile ilgili sorumlu kişilerin bulunduğu belirlenmiştir.

Deneylerde oluşan atıklar ve onların riski deneylerde kullanılan kimyasallarla ilişkilidir [19]. Birçok laboratuvarda yapılan deneylere göre bazı çözeltiler taze hazırlanır [20]. Bu yüzden bu çözeltiler gereksinim duyuldukları hacimde hazırlanarak deneysel atık oluşumu önemli ölçüde azaltılabilir. Ankete verilen yanıtlara göre laboratuvarlarda daha az atık üretmek amacıyla 94 laboratuvarın yeni çalışmalar sürdürdüğü belirlenmiştir. Laboratuvarlarda en fazla tüketilen materyal koruyucu eldivenlerdir. Bu eldivenler kağıt kutular içinde paketlenmektedir. Satın alırken geri dönüştürülmüş kâğıt kullanılan paketlerdeki eldivenler tercih edilmelidir. Laboratuvarda kullanılan geri dönüştürülemeyen diğer materyaller yerine geri dönüştürülebilen materyal kullanımına geçilmelidir. Bu geri dönüştürülmüş ürünlerin satın alınması, satıcılar arasındaki ekolojik eğilime katkı sağlar ve ürünlerinde daha fazla geri dönüştürülmüş malzemenin kullanılmasına teşvik eder [21]. Türkiye'deki çevre laboratuvarlarında az sayıda (58) laboratuvar geri dönüşümlü kâğıt kullanmakta dır. Konu ile ilgili "Laboratuvarınızda tek kullanımlık ürünler yerine yeniden kullanılabilir malzeme ve geri dönüştürülebilir kimyasallar kullanılıyor mu?" sorusuna az sayıda (58) laboratuar evet yanıtını vermiştir. Yine laboratuvara bir ürün satın alınırken geri dönüştürülebilen ambalaj kullanılmış olmasına dikkat eden laboratuar sayısı 94 tür. Ancak 163 laboratuvar kendi laboratuvarında geri dönüştürülebilecek veya yeniden kullanılabilecek her türlü materyal ve malzemeyi değerlendirdiğini, 158 laboratuvar laboratuvarda oluşan atık pillerin geri dönüşüme gönderildiğini belirtmiştir. Laboratuvarlar çevresel etkilerini oluklu karton, çalışma kağıtları, kutular gibi kağıt atıklar plastik pipet ucu, cam eşyalar, bataryalar vs. geri kazanarak veya yeniden kullanarak (örneğin mikropipet kutularının üzerindeki plastik kapak depolama veya yıkama kabı olarak yeniden kullanılabilir) azaltırlar[22].

Laboratuvar katologları laboratuvarda oluşan kağıt atıklar arasında ilk sıralarda yer alır. Bu katologların basılı versiyonları yerine elektronik ve online alışverişi tercih etmek laboratuvarlarda oluşan atık kağıt miktarını azaltacaktır. Türkiye'deki çevre laboratuvarlarının yarısı katologların basılı versiyonları yerine elektronik ve online alışverişi tercih etmektedir. Türkiye'deki çevre laboratuvarlarının büyük çoğunluğu (156 laboratuvar) laboratuvarlarda oluşan kutu ve ambalajların geri dönüşümünün veya satılmasının mümkün olduğunu düşünmektedir. $\mathrm{Bu}$ çalışma da anketlere verilen yanıtlara göre Türkiye'deki çevre laboratuvararının 
farkındalığının geri dönüşüm konusunda düşük, ancak kendi laboratuvarlarında oluşan atıkların geri kazanımı veya yeniden kullanımı ile ilgili ise yüksek olduğu belirlenmiştir. Yeşil laboratuar sertifikası ülkemizde popülerite kazandığında konu ile ilgili farkındalığın artacağı şüphesizdir.

Laboratuvarlar önemli miktarlarda solvent, atıksu, biyolojik veya kimyasal tehlikeli atıklar üretir[8]. Laboratuvarlarda bitkisel içerikli laboratuvar materyallerini tercih etmek, cam ve diğer materyallerin temizliğinde yeşil sertifikalı temizlik ürünlerini kullanmak çevresel etkilerin azaltılmasına önemlidir. Türkiye'deki Çevre Laboratuvarlarının 49 laboratuvarda yeşil sertifikalı temizlik ürünleri kullanılmakta ve 51 laboratuvarda bitkisel içerikli laboratuar materyalleri tercih edilmektedir. Deneylerde kullanılan çok küçük miktarlardaki toksik elementlerin geri dönüşümü ve yeniden kullanımı benzer toksiktürlerle birlikte yapılabilir. Deneyler çevresel etkileri azaltacak ancak bu bileşiklerin pahalı bertaraf maliyetlerinden kaçınılacak şekilde tasarlanmalıdır [19]. Kanserojen olduğu bilinen kimyasallarla çalışlırken, depolarken dikkat edilmeli bu atıkların yönetimi tehlikeli madde bertaraf servisi tarafindan gerçekleştirilmelidir [22]. Bu çalışma da anketlere verilen yanıtlara göre Türkiye'deki Çevre Laboratuvarlarının büyük çoğunluğu (165 laboratuvar) laboratuarlarında kimyasalların güvenli bir şekilde depolandığını, tehlikeli kimyasalları tanımlayıp daha az tehlikeli alternatiflerinikullandığını (155 laboratuvar) ancak çok az laboratuvar (51 laboratuvar) halojenli reaktifleri kullanmaktan sakındığını belirtmiştir. Özellikle distilasyon deneylerinde soğutucu olarak musluk suyu kullanılır. Bu işlem çok fazla su tüketimine neden olur. Kendi haznesi bulunan soğutuculu sirkülatör kullanılarak aynı anda birden fazla deneydesusirküle edilerek su tasarrufu sağlanabilir [18].Laboratuvarlarda saf su üretimi de hem enerji hem de su tüketimine neden olmaktadır. Saf su laboratuar malzemeleri temizlendikten sonra nihai işlem olarak kullanılmalıdır [21]. Bu çalışma da "Laboratuvar personeli su tüketimini azaltmak için teşvik ediliyor mu? Laboratuvar personeli bina yöneticilerine lavabo veya herhangi bir borudaki su sizıntısını rapor etme sürecini biliyor mu? sorusunaaz sayıda (55) laboratuvar evet yanıtını vermiştir. Laboratuvarda yıkama tekniği oluşturmak (örneğin bir kez deterjanlı su, bir kez musluk suyu, bir kez yıkama asidi, bir kez tekrar musluk suyu, bir kez çözücü ve nihayetinde saf su ile yıkama işlemini tamamlamak gibi) rastgele yapılan yıkama işleminden daha az saf su ve musluk suyu tüketimine neden olur. Bu konu ile ilgili Türkiye'deki çevre laboratuarlarının çok az kısmı (78 laboratuvar) "Laboratuvarınızda uygun yıkama teknikleri oluşturulmuş ve uygulanıyor mu? Laboratuvar personeli laboratuvar malzemelerini yıkama işleminde su tüketimini azaltan teknikleri biliyorlar mı? Sorusuna evet yanıtııı vermiştir. Ancak 158 laboratuvar cam malzemelerin temizliğinde minimum çözücü kullandığını belirtmiştir. Laboratuvarların eğitim ile ilgili faaliyetleri belirlemek amacıyla "Laboratuvar da panolara sürdürülebilir çalışmalarla ilgili bilgilendirmeler yapıldı mı?" sorusu sorulmuş sadece 55 laboratuvar "evet" yanıtını vermiştir. Son olarak laboratuvarlara çevresel etkilerini azaltmak amacıyla yapmayı planladıkları faaliyetleri sorulduğunda distilasyon ünitelerinde kullanılan soğutma suyunun sirküle ederek su tasarrufu sağlamayı, atık oluşumunu kaynağında azaltmayı, daha az kimyasal ile deneyleri tasarlamayı, atıksularını yeniden kullanmayı planladıklarını belirtmişlerdir.

Bu çalışma da Türkiye'de çevre laboratuvarlarının çevresel sürdürülebilirliğini belirlemede yeşil laboratuar ilkeleri temel alınmıştır. Anketlerden elde edilen yanıtlara göre her bir laboratuvar için puan hesaplaması yapılmış, Türkiye'de 170 çevre laboratuvarının yeşil laboratuvar puanlandırma ilkelerine göre genel değerlendirmesi Tablo 3'de verilmiştir.

Tablo 3. 170 Çevre Laboratuarının yeşil laboratuvar puanlandırma ilkelerine göre genel değerlendirmesi

\begin{tabular}{ccccc}
\hline Yeşil Lab.Sertifikası & Bronz & Gümüş & Altın & Platin \\
\hline 64 & 26 & 19 & 22 & 37 \\
\hline
\end{tabular}

Yapılan değerlendirme anketlere verilen yanıtlara göre yapıldığı için kriterleri sağlamada esas ölçüt olarak değil ön değerlendirme olarak düşünülmüştür. Çalışma da sadece 2 laboratuvar yeşillaboratuar sertifikasına uygun değilken 37 laboratuvar yeşil laboratuar sertifikasına uygun hatta platin olarak belirtilen en üst seviyededir. Yeşil laboratuvar sertifikasını alabilecek durumda olan laboratuvarların platin seviyeye ulaşabilmesi içinçevre duyarlılı̆ı̆na, sürdürülebilir-yenilenebilir kaynak kullanımına önem vermesi gerekmektedir. Bu çalışma da Türkiye'deki çevre laboratuvarlarının yeşil laboratuvar ilkerine tam uygunluğunu sağlamada eksiklikleri; laboratuvarlarında halojenli reaktifleri kullanmaları, bitkisel içerikli laboratuvar materyallerini ve temizlik malzemelerini tercih etmemeleri, deneylerin çevreye zararlı kimyasalları kullanmak yerine geri kazanılabilen ve çevreye daha az zararlı kimyasallar tercih ederek tasarlanmadığı, online alışverişin tercih 
edilmeyerek kaynak israfı yapılması, enerji verimliliğini arttırmada tedbirlerin ve geri dönüşüm ile ilgili faaliyetlerin yetersiz olması olarak tespit edilmiştir.

\section{KAYNAKLAR}

[1] FAS Green Lab Certification. Harvard Faculty of Arts and Sciences. (2011). http://www.green.harvard.edu/fas-green-lab-certification-overview.

[2] ISO 14024, Environmental labels and declarations - Type I Environmental labeling Principles and Procedures, ISO, 1999.

[3] ISO 14021, Environmental Labels and Declarations-Self-declared environmental claims (Type II Environmental labeling), ISO, 1999.

[4] ISO 14040, Environmental management - Life Cycle Assessment - Principles and framework, 2006.

[5] İyi Laboratuvar Uygulamaları Prensipleri, Test Birimlerinin Uyumlaştırılması, İyi Laboratuvar Uygulamalarının ve Çalışmaların Denetlenmesi Hakkında Yönetmelik 2010. (R.G tarih ve sayı:09.03.201027516)

[6] The Yale Green Laboratories Certification Program, The Yale Department of Environmental Health and Safety. http://www.yale.edu/ehs/sustainability/greenlabs.htm

[7] ABDEL-RAHIM, M., CANEZO, L., COTTRELl, B., GUNTHER, W., LIU, J., The University of South Florida Green Lab Guide, Campus Ecology, University of South Florida, 2011.

[8] NOLAN, D., LEBANSKY, R., PETERSON, C., Developing A Green Laboratory Self-Evaluation Program, GARRISON, M., \& WILSON, BB., (Eds.), Sustainability on the UT Campus, 75-79, 2010.

[9] ANASTAS, PT., WARNER, JC., Green Chemistry: Theory and Practice, Oxford University Press: New York, p.30, 1998.

[10] Laboratories for the 21st Century: Best Practice Guide - Optimizing Laboratory Ventilation Rates, 2016. http:// www.i2sl.org/documents/toolkit/bp_opt_vent_508.pdf.

[11] SOMERVELL, D., MCGRATH, T., Intern The University of Edinburgh Auditing and Improving Energy Efficiency at the University of Edinburgh Cancer Research CentreLaboratory Environmental Improvement Workshop, 23 April 2010.

[12]BORCHARDT, JK., “Achieving Laboratory Energy Efficiency”, Lab Manager Magazine, 4(3), 16-19, 2009.

[13] MILLS, E., SARTOR, D., "Energy Use and Savings Potential For Laboratory Fume Hoods", Energy, 30,1859-1864, 2005.

[14]REINDORF, L., GOLDMAN, M., Retrofitting Labs to Reduce Energy Consumption, 16,1,2011. http://www.rdmag.com/Lab-Design-News/Articles/2011/02/Sustainability-Retrofitting-Labs-To-ReduceEnergy-Consumption/

[15] DE PALMA, AK., "Fume Hoods: Ductless Models at Forefront of “Green” Lab Movement", Lab Manager Magazine, 6(3), 45-46, 2011.

[16] RAPHAEL, J.R, Unplug for Dollars: Stop 'Vampire Power' Waste. PC World, 2008. http://www.pcworld.com/article/153245/unplug_for_dollars_stop_vampire_power_waste.html.

[17]DAUES, J., Green Labs Pilot Program Ends with Significant Energy Savings, 2012. http://news.wustl.edu/news/Pages/23543.aspx

[18]BCST \& DELS (Board on Chemical Sciences and Technology and Earth and Life Sciences), Prudent Practices in the Laboratory: Handling and Management of Chemical Hazards, ISBN-13: 978-0-30913865-9. Washington, DC, 2011.

[19]CPSMA \& DELS (Commission on Physical Sciences, Mathematics, and Applications and Earth and Life Sciences), Prudent Practices in the Laboratory: Handling Disposal of Chemicals. ISBN-13: 978-0-30913865-9, Washington, DC, 1995.

[20]CARSON, V., Analytical Chemistry Lab Manual, Analytical Chemistry, CHM 3120, 2012.

[21]BUIE J., MindMap: Reduce My Lab's Environmental Impact. Lab Manager Magazine, 6(3), 70-71. 2011.

[22] POLlENZ, R.S., KIMBLE, M., CANNONS, A., Experiments in Cell Biology. Dubuque, Iowa: Kendall/Hunt Publishing Company. 37-44, 2008. 